\title{
Lead and Cadmium Concentrations in the Hair of Fishermen from the Subae River Basin, Brazil
}

\author{
F. Carvalho, ${ }^{* 1}$ Tania M. Tavares, ${ }^{*}$ Sandra P. Souza, $\dagger$ and \\ P. S. LINHARES* \\ *University of Bahia, and †CEPED, State of Bahia, Brazil \\ Received September 9, 1982
}

\begin{abstract}
Previous studies have shown heavy pollution by lead and cadmium in the Subae River basin, State of Bahia, Brazil, caused by a lead smelter. Concentrations of these metals were determined in scalp hair of fishermen from three riverside towns and from a reference town. Increased levels for both metals were associated with increasing proximity to the smelter. Mean concentrations of lead and cadmium were higher among fishermen with straight hair than among those with curly hair. The effects of hair washing, hair type, and color and age on metal concentrations in fishermen's hair were studied.
\end{abstract}

\section{INTRODUCTION}

Since 1960 a primary lead smelter has been operating in the outskirts of Santo Amaro City, State of Bahia, Brazil (Fig. 1). Since its initiation it has been polluting the Subae River heavily. At least 2.5 tons of cadmium were dumped directly into the Subae River and another 1.5 tons released to the air. Total lead burden is difficult to estimate.

The environmental contamination was studied by Reis (1975) who showed that mean lead and cadmium concentrations in the Subae River water exceeded the World Health Organization (1977) tolerance limits by 16 and 8 times, respectively. Souza et al. (1978) found high concentrations of cadmium in local oysters, fish, crabs, and shrimps. Oysters (Crassostrea rhizophorae) are part of the usual diet of these populations and were particularly contaminated, mean concentration of cadmium averaging $120 \mathrm{ppm}$, ranging from 80 to $135 \mathrm{ppm}$, on dry weight basis. However, Carvalho (1978) did not find a significant association between the prevalence of proteinuria (sulfosalicylic acid method) and the ingestion of this local seafood by fishermen.

Despite the fact that no data on lead and cadmium in air were available, the aerial route should be an important source of human contamination by these metals. Emission of particulate metals to the atmosphere was uncontrolled because of the lack of adequate filters and very short chimneys (Carvalho, 1982).

We studied fishermen from the Subae River basin for absorption of lead and cadmium in relation to a reference population.

\footnotetext{
${ }^{1}$ To whom correspondence should be addressed: Mestrado em Saúde Comunitária da UFBa, Anexo II da Faculdade de Medicina, Rua Padre Feijó, s/n Canela, 40.000 Salvador, Bahia, Brazil.
} 


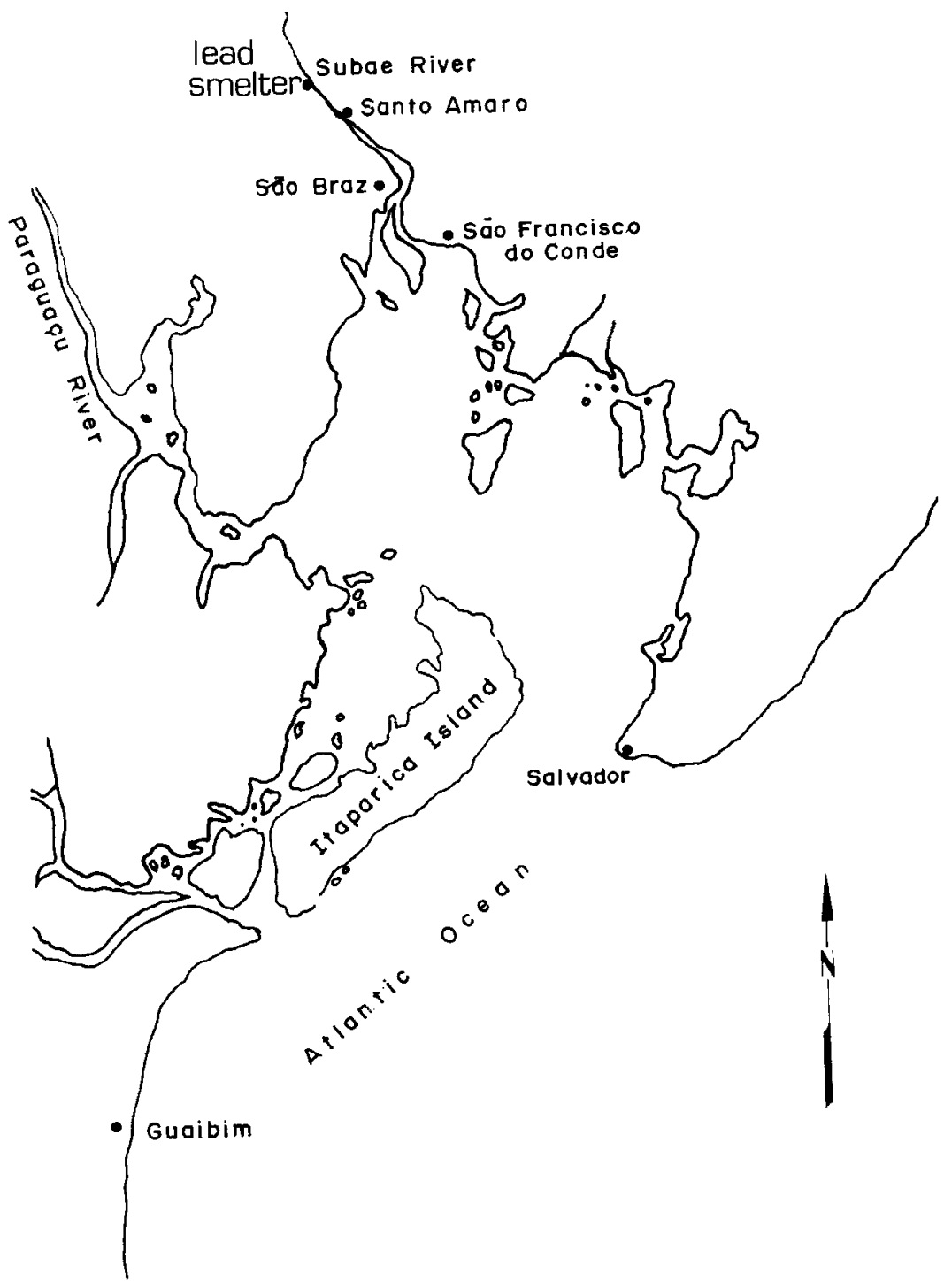

FIGURE 1.

\section{MATERIALS AND METHODS}

Simple random samples of 32,35 , and 52 fishermen were taken from riverside towns of Santo Amaro, Sao Braz, and Sao Francisco (sampling fractions: 0.55, $0.36,0.23$ ), respectively. Distances from the smelter were $3.5,5.0$, and $7.5 \mathrm{~km}$, respectively. A reference population of 64 fishermen (sampling fraction: 0.77 ) was taken from Guaibim, a fishing village $84 \mathrm{~km}$ from the smelter. All 183 fishermen were males aged 18 to 77 years. Standards of living were very low for all four populations. 
A hair sample was taken from each fisherman, hair strings being cut at the same distance from the scalp. Each sample was treated independently: about 1 $\mathrm{g}$ of hair was soaked for $1 \mathrm{hr}$ in $50 \mathrm{ml}$ of $10 \%$ neutral Extran with occasional stirring, then rinsed with deionized water and let to dry. The dried portion was transferred to a digestion pump, weighed with precision to $0.1 \mathrm{mg}$, and digested with $5 \mathrm{ml} \mathrm{HNO}$ (concentrated) at $105^{\circ} \mathrm{C}$ for $8 \mathrm{hr}$. Readings were taken on an atomic absorption spectrophotometer Model 306, with graphite furnace HGA 2000, Perkin-Elmer (A Report, 1976).

Bartlett's test of homogeneity of variances (Kendall and Stuart, 1969) was applied to the data in Tables 1 and 2. Subsequent comparisons among town means were done by the Mann-Whitney test (Siegel, 1956). This same test was used to compare means, inside each town, for data on hair type, hair washing, and hair color.

Log $\mathrm{PbH}$ and $\log \mathrm{CdH}$ represent, respectively, data on lead and cadmium concentrations in hair after logarithmic transformation, base 10.

\section{RESULTS}

Table 1 shows concentrations of lead in hair $(\mathrm{PbH})$ and Table 2 of cadmium in hair $(\mathrm{CdH})$ among fishermen from the four towns. $\overline{\mathrm{X}}$ represents the arithmetic mean; $\mathrm{GM}$ and $\mathrm{SD}_{\mathrm{GM}}$, the geometric mean and its respective standard deviation.

Each of the three populations from the Subae River area had higher $\mathrm{PbH}$ and $\mathrm{CdH}$ mean levels than those found in the reference population. Statistical significance levels for these comparisons were much higher for Santo Amaro $(P<$ $0.00005)$, followed by those found in Sao Braz $(P<0.0005)$, and finally by those found in Sao Francisco $(P<0.01$ for $\mathrm{PbH}$ and $P<0.05$ for $\mathrm{CdH})$.

Comparisons of $\mathrm{PbH}$ and $\mathrm{CdH}$ levels among fishermen from the three Subae River towns showed that those from Santo Amaro were more contaminated than those from Sao Braz $(P<0.00005$ for each metal) and from Sao Francisco $(P<$ 0.00005 for each metal). However, fishermen from Sao Braz had identical $\mathrm{PbH}$ and $\mathrm{CdH}$ means to those from Sao Francisco at the 5\% significance level (not shown at Tables 1 and 2).

Table 3 shows that concentrations of lead and cadmium in hair were linearly related in fishermen from each town. Higher levels of association were observed in the polluted areas than in the reference area.

As can be seen in Table 4 fishermen with straight hair always presented higher

TABLE 1

Concentrations of Lead in Scalp Hair ( $\mathrm{PbH}$, ppm) of Fishermen from Subae River Towns AND FROM REFERENCE TOWN (GUAIBIM)

\begin{tabular}{lcccccc}
\hline \multicolumn{1}{c}{ Town } & $N$ & $\overline{\mathrm{X}}$ & $\mathrm{GM}$ & $\mathrm{SD}_{\mathrm{GM}}$ & Range & \multicolumn{1}{c}{$\boldsymbol{P}$} \\
\hline Santo Amaro & 32 & 90.3 & 39.6 & 3.18 & $2-1168$ & $<0.00005$ \\
Sao Braz & 35 & 22.3 & 13.4 & 2.41 & $2-161$ & $<0.0005$ \\
Sao Francisco & 52 & 23.9 & 11.1 & 2.90 & $0-497$ & $<0.01$ \\
Guaibim & 64 & 13.3 & 6.9 & 3.20 & $0-87$ & - \\
\hline
\end{tabular}


TABLE 2

Concentrations of Cadmium in Scalp Hair (CdH, ppm) of Fishermen from Subae River TOWNS AND FROM REFERENCE TOWN (GUAIBIM)

\begin{tabular}{lcccccc}
\hline \multicolumn{1}{c}{ Town } & $N$ & $\overline{\mathrm{X}}$ & $\mathrm{GM}$ & $\mathrm{SD}_{\mathrm{GM}}$ & Range & \multicolumn{1}{c}{$P$} \\
\hline Santo Amaro & 32 & 1.72 & 1.01 & 2.70 & $0.18-9.89$ & $<0.00005$ \\
Sao Braz & 35 & 0.67 & 0.36 & 2.47 & $0.06-9.63$ & $<0.0005$ \\
Sao Francisco & 52 & 0.84 & 0.27 & 2.69 & $0.02-1.48$ & $<0.05$ \\
Guaibim & 64 & 0.97 & 0.15 & 4.18 & $0.01-4.20$ & - \\
\hline
\end{tabular}

$\mathrm{PbH}$ and $\mathrm{CdH}$ mean concentrations than those with curly hair. As related to $\mathrm{PbH}$ levels, these differences were statistically significant among fishermen from Santo Amaro $(P<0.01)$ and from Sao Francisco $(P<0.05)$. In relation to CdH levels, differences were statistically significant only among fishermen from Sao Francisco $(P<0.01)$.

In all towns, fishermen who used to wash their hair with soap had lower $\mathrm{PbH}$ and $\mathrm{CdH}$ mean concentrations than those who used only water (Table 5). However, not one of these differences reached the $5 \%$ significance level. Only one fisherman, from Sao Braz, declared he used to wash his hair with shampoo twice a week.

No marked differences in $\mathrm{PbH}$ and $\mathrm{CdH}$ mean levels were found $(P>0.05)$ in respect to hair color within each town (Table 6).

Linear regression equations were calculated for $\log \mathrm{PbH}$ and $\log \mathrm{CdH}$ in relation to age, for each town. No statistical associations were found at the 5\% significance level.

\section{DISCUSSION}

Dosages of lead and cadmium in human hair have proved to be useful indexes of absorption following environmental exposure to these metals (Hammer $e t$ al., 1971; Klevay, 1973; Chattopadhyay et al., 1977; Kowal et al., 1979). In this study, $\mathrm{PbH}$ and $\mathrm{CdH}$ concentrations showed that the absorption by the fishermen increased with increasing proximity to the smelter.

Carvalho et al. (1979) found that these same fishermen from Santo Amaro and

TABLE 3

Linear Regression Equations for ConCEntrations of log PbH, ppm ( $Y$ ) on log CdH, and ppm $(X)$ of Fishermen from Subae River Towns and from Reference Town (Guaibim)

\begin{tabular}{llllll}
\multicolumn{1}{c}{ Town } & $N$ & Equation & $r^{a}$ & $P^{b}$ \\
\hline Santo Amaro & 32 & $Y=1.595+0.502 . X$ & 0.43 & $\leqslant 0.007$ \\
Sao Braz & 35 & $Y=1.290+0.362 . X$ & 0.37 & $\leqslant 0.01$ \\
Sao Francisco & 52 & $Y=1.425+0.607 . X$ & 0.52 & $\leqslant 0.00004$ \\
Guaibim & 64 & $Y=0.912+0.098 . X$ & 0.12 & $\leqslant 0.17$ \\
\hline
\end{tabular}

${ }^{a} r=$ correlation coefficient.

${ }^{b} P=$ significance of the slope. 
TABLE 4

Concentrations of Lead and Cadmium in Scalp Hair of Fishermen from Subae River Towns AND FROM REFERENCE TOWN (GUAIBIM) BY HAIR TYPE

\begin{tabular}{|c|c|c|c|c|c|c|c|c|}
\hline \multirow[b]{2}{*}{ Town } & \multirow{2}{*}{$\begin{array}{l}\text { Hair } \\
\text { type }\end{array}$} & \multirow[b]{2}{*}{$N$} & \multicolumn{3}{|c|}{$\mathrm{PbH}$} & \multicolumn{3}{|c|}{$\mathrm{CdH}$} \\
\hline & & & GM & $\mathrm{SD}_{\mathrm{GM}}$ & $P$ & $\mathrm{GM}$ & $\mathrm{SD}_{\mathrm{GM}}$ & $P$ \\
\hline \multirow[t]{2}{*}{ Santo Amaro } & Straight & 11 & 86.4 & 3.09 & \multirow{2}{*}{$<0.01$} & 1.17 & 2.53 & \multirow{2}{*}{$>0.0$} \\
\hline & Curly & 16 & 25.4 & 2.93 & & 0.90 & 2.97 & \\
\hline \multirow[t]{2}{*}{ Sao Braz } & Straight & 4 & 19.0 & 6.10 & \multirow{2}{*}{$>0.05$} & 0.56 & 1.97 & \multirow{2}{*}{$>0.0$} \\
\hline & Curly & 29 & 12.7 & 2.12 & & 0.33 & 2.54 & \\
\hline \multirow[t]{2}{*}{ Sao Francisco } & Straight & 5 & 44.7 & 4.64 & \multirow{2}{*}{$<0.05$} & 0.66 & 1.54 & \multirow{2}{*}{$<0.01$} \\
\hline & Curly & 47 & 9.8 & 2.48 & & 0.22 & 2.43 & \\
\hline \multirow[t]{2}{*}{ Guaibim } & Straight & 5 & 6.7 & 4.02 & \multirow{2}{*}{$>0.05$} & 0.21 & 2.60 & \multirow{2}{*}{$>0.0$} \\
\hline & Curly & 58 & 6.6 & 3.08 & & 0.15 & 4.38 & \\
\hline
\end{tabular}

from Sao Braz had higher levels of $\delta$-aminolevulinic acid in urine than the reference group from Guaibim town $(P<0.05)$. This further evidence indicates that, beyond being absorbed, environmental lead is impairing heme biosynthetic pathways of these fishermen. Recently, Carvalho (1982) carried out a survey among 642 children 1- to 9-years-old living at less than $900 \mathrm{~m}$ from the Santo Amaro smelter. Geometric mean of zinc protoporphyrin concentrations was $1.29 \pm 2.26$ $\mu \mathrm{mol} / \mathrm{liter}$ and the arithmetic mean of blood lead levels was $2.84 \pm 1.20 \mu \mathrm{mol} /$ liter. Carvalho (1978) determined prevalence rates of proteinuria by the sulfosalicylic acid method among fishermen from these four towns. Rates were higher, in Santo Amaro (7.0\%), Sao Braz (7.2\%), and Sao Francisco (5.6\%) than in Guaibim (4.8\%). However, these differences were not statistically significant at the $5 \%$ level.

Both contaminated and reference populations presented here had $\mathrm{CdH}$ mean levels somewhat lower than those recorded in other studies, carried out among non-occupationally exposed adult males (Petering et al., 1973; Oleru, 1975; Gross et al., 1976; Kowal et al., 1979).

TABLE 5

Concentrations of Lead and Cadmium in Scalp Hair of Fishermen from Subae River Towns AND FROM REFERENCE TOWN (GUAIBIM) BY HAIR WASHING

\begin{tabular}{|c|c|c|c|c|c|c|}
\hline \multirow[b]{2}{*}{ Town } & \multirow{2}{*}{$\begin{array}{l}\text { Hair } \\
\text { wash }\end{array}$} & \multirow[b]{2}{*}{$N$} & \multicolumn{2}{|c|}{$\mathrm{PbH}$} & \multicolumn{2}{|c|}{$\mathrm{CdH}$} \\
\hline & & & GM & $\mathrm{SD}_{\mathrm{GM}}$ & GM & $\mathrm{SD}_{\mathrm{GM}}$ \\
\hline \multirow[t]{2}{*}{ Santo Amaro } & Water & 7 & 53.3 & 1.86 & 1.09 & 2.16 \\
\hline & Soap & 23 & 36.4 & 3.74 & 1.03 & 2.93 \\
\hline \multirow[t]{2}{*}{ Sao Braz } & Water & 5 & 19.5 & 6.02 & 0.52 & 2.41 \\
\hline & Soap & 27 & 12.8 & 2.00 & 0.34 & 2.51 \\
\hline \multirow{2}{*}{ Sao Francisco } & Water & 7 & 16.0 & 2.39 & 0.27 & 2.06 \\
\hline & Soap & 43 & 10.9 & 3.04 & 0.24 & 2.63 \\
\hline \multirow[t]{2}{*}{ Guaibim } & Water & 6 & 9.7 & 4.04 & 0.28 & 4.18 \\
\hline & Soap & 58 & 6.6 & 3.15 & 0.14 & 4.18 \\
\hline
\end{tabular}


TABLF 6

Concentrations of Lead and Cadmium in Scalp Hair of Fishermen from Subae River Towns AND FROM REFERENCE TOWN (GUaibim) By HaIR COLOR

\begin{tabular}{|c|c|c|c|c|c|c|}
\hline \multirow[b]{2}{*}{ Town } & \multirow{2}{*}{$\begin{array}{l}\text { Hair } \\
\text { color }\end{array}$} & \multirow[b]{2}{*}{$N$} & \multicolumn{2}{|c|}{$\mathrm{PbH}$} & \multicolumn{2}{|c|}{$\mathrm{CdH}$} \\
\hline & & & GM & $\mathrm{SD}_{\mathrm{GM}}$ & $\mathrm{GM}$ & $\mathrm{SD}_{\mathrm{GM}}$ \\
\hline \multirow[t]{3}{*}{ Santo Amaro } & White/Grey & 14 & 36.5 & 2.41 & 1.04 & 2.96 \\
\hline & Brown & 8 & 43.4 & 4.44 & 0.96 & 3.33 \\
\hline & Black & 6 & 51.3 & 5.25 & 1.02 & 1.70 \\
\hline \multirow[t]{3}{*}{ Sao Braz } & White/Grey & 3 & 26.2 & 5.08 & 0.58 & 3.19 \\
\hline & Brown & 16 & 13.9 & 1.98 & 0.37 & 2.88 \\
\hline & Black & 16 & 11.4 & 2.48 & 0.31 & 2.02 \\
\hline \multirow[t]{3}{*}{ Sao Francisco } & White/Grey & 13 & 10.9 & 2.81 & 0.26 & 2.26 \\
\hline & Brown & 20 & 10.8 & 3.57 & 0.21 & 2.69 \\
\hline & Black & 19 & 12.2 & 2.43 & 0.27 & 2.50 \\
\hline \multirow[t]{3}{*}{ Guaibim } & White/Grey & 12 & 6.7 & 3.07 & 0.27 & 2.88 \\
\hline & Brown & 6 & 4.4 & 4.31 & 0.14 & 2.28 \\
\hline & Black & 46 & 7.3 & 3.16 & 0.13 & 4.74 \\
\hline
\end{tabular}

Petering et al. (1973) studied a non-occupationally exposed population with similar age and sex composition. $\mathrm{PbH}$ mean level was $44.4 \mathrm{ppm}$ which is still higher than values observed in the present study. $\mathrm{PbH}$ mean values for nonoccupationally exposed groups vary widely due to differences in biological characteristics among study populations (Schroeder and Nason, 1969; Hammer et al., 1971; Klevay, 1973; Chattopadhyay et al., 1977). Comparisons of $\mathrm{PbH}$ and $\mathrm{CdH}$ levels among various studies can lead to fallacious conclusions due to different analytical methods (Friberg et al., 1974; Kopito and Shwachman, 1974).

For males aged 2 to 88 years, Petering et al. (1973) found that $\log \mathrm{PbH}$ and $\log$ $\mathrm{CdH}$ were highly associated $(r=0.40 ; P<0.001)$. Similarly high levels of association were observed between these two variables among fishermen from the Subae River area.

Fishermen with straight hair presented higher $\mathrm{PbH}$ and $\mathrm{CdH}$ concentrations than those with curly hair. These variations seem to depend more on biological factors than on exposure level. The effect of different racial groups on these results was not assessed because the high racial admixture prevailing in this population makes this task particularly difficult.

Constantly lower $\mathrm{PbH}$ and $\mathrm{CdH}$ levels were observed among fishermen who used to wash their hair with soap, instead of only water. It is a well-known fact that nonionic detergents and organic solvents are effective in removing heavy metals from hair surface (Friberg et al., 1974; Grandjean, 1978). Therefore, a possible explanation for the figures observed in Table 5 is that the poor-quality, alkaline soap commonly used by these fishermen would attack the hair surface. In this way, certain amounts of endogenous lead and cadmium could be removed.

No significant differences at the $5 \%$ level were found in $\mathrm{PbH}$ and $\mathrm{CdH}$ means in relation to hair color. Schroeder and Nason (1969) found that, among males, brown hairs accumulated more lead and cadmium than black ones. As in our study, they also found that white and grey hairs did not have higher lead and cadmium concentrations than natural colored hairs at the 5\% significance level. 
As in the present study, Petering et al. (1973) did not find statistical association $(P>0.05)$ between $\log \mathrm{PbH}$ and $\log \mathrm{CdH}$ and age, using linear regression.

Summarizing, variations observed among the biological parameters cited above were very useful to explain some differences in $\mathrm{PbH}$ and $\mathrm{CdH}$ indexes among the four fishermen populations. However, the main point which emerged from this study was the human contamination by lead and cadmium caused by gross environmental pollution produced by the industry.

\section{REFERENCES}

Carvalho, F. (1978). Intoxicação por chumbo e cádmio entre pescadores da região do Rio Subaé e de Guaibim (área controle). Thesis, University of Bahia, Brazil. 107 p. (Portuguese, summary in English).

Carvalho, F. (1982). Anaemia amongst Brazilian children. Thesis, University of London, TUC Centenary Institute of Occupational Health. $282 \mathrm{p}$.

Carvalho, F., Tavares, T. M., Souza, S. P., Linhares, P., and Sinha, B. K. (1979). Estudos dos efeitos da exposição de pescadores de região do Subaé ao chumbo e cádmio. Camaçari, Bahia, 107 p., mimeo (Portuguese, summary in English).

Chattopadhyay, A., Roberts, T. M., and Jervis, R. E. (1977). Scalp hair as a monitor of community exposure to lead. Arch. Environ. Health 32, 226-236.

Friberg, L., Piscator, M., Nordberg, G., and Kjellström, T. (1974). "Cadmium in the environment." 2nd ed. CRC Press, Cleveland.

Grandjean, P. (1978). Lead concentration in single hairs as a monitor of occupational lead exposure. Int. Arch. Occup. Environ. Health 42, 69-81.

Gross, S. B., Yeager, D. W., and Middendorf, M. S. (1976). Cadmium in liver, kidney, and hair of humans, fetal through old age. J. Toxicol. Environ. Health 2, 153-167.

Hammer, D. I., Finklea, J. F., Hendricks, R. H., Shy, C. M., and Horton, R. J. M. (1971). Hair trace metal levels and environmental exposure. Amer. J. Epidemiol. 93, 84-92.

Kendall, M. G., and Stuart, A. (1969). "The Advanced Theory of Statistics." Griffin, New York.

Klevay, L. M. (1973). Hair as a biopsy material. III. Assessment of environmental lead exposure. Arch. Environ. Health 26, 169-172.

Kopito, L., and Shwachman, H. (1974). All this lead. Arch. Environ. Health 29, 296.

Kowal, N. E., Johnson, D. E., Kraemer, D. P., and Pahren, H. R. (1979). Normal levels of cadmium in diet, urine, blood, and tissues of inhabitants of the United States. J. Toxicol. Environ. Health 5, 995-1014.

Oleru, U. G. (1975). Epidemiological implications of environmental cadmium. I. The probable utility of human hair for occupational trace metal (cadmium) screening. Amer. Ind. Hyg. Assoc. J. 36, 229-233.

Petering, H. G., Yeager, D. W., and Witherup, S. O. (1973). Trace metal content of hair. II. Cadmium and lead of human hair in relation to age and sex. Arch. Environ. Health. 27, 327-330.

Reis, J. O. N. (1975). Determinação polarografica de $\mathrm{Pb}^{+2} \mathrm{e} \mathrm{Cd}^{+2}$ em águas do Rio Subaé-Sto. AmaroBahia. Thesis, University of Bahia, Brazil. 81 p. (Portuguese, summary in English).

A Report prepared by the mercury analysis working party of the Bureau International Technique du clore (1976). Analyt. Chim. Acta. 84, 231.

Schroeder, H. A., and Nason, A. P. (1969). Trace metals in human hair. J. Invest. Dermatol. 53, 71-78.

Siegel, S. (1956). "Nonparametric Statistics for the Behavioral Sciences." McGraw-Hill, New York.

Souza, S. P., Ferreiro, M. F., Fernandes, J., Tavares, T. M., and Brandão, A. M. (1978). Distribuiçâo de chumbo, cádmio e zinco em sedimentos e fauna do Rio Subaé. Resumos do V Simpósio Latinoamericano sobre Oceanografía Biológica, São Paulo, p. 19-20 (Portuguese).

World Health Organization (1977). "International Standards for Drinking Water." 2nd ed. WHO, Geneva. 